IZA DP No. 6118

\title{
Profit Sharing and Training
}

Kornelius Kraft

Julia Lang

November 2011 


\title{
Profit Sharing and Training
}

\author{
Kornelius Kraft
}

TU Dortmund,

ZEW and IZA

\author{
Julia Lang
}

TU Dortmund

\section{Discussion Paper No. 6118 \\ November 2011}

\author{
IZA \\ P.O. Box 7240 \\ 53072 Bonn \\ Germany \\ Phone: +49-228-3894-0 \\ Fax: +49-228-3894-180 \\ E-mail: iza@iza.org
}

\begin{abstract}
Any opinions expressed here are those of the author(s) and not those of IZA. Research published in this series may include views on policy, but the institute itself takes no institutional policy positions.

The Institute for the Study of Labor (IZA) in Bonn is a local and virtual international research center and a place of communication between science, politics and business. IZA is an independent nonprofit organization supported by Deutsche Post Foundation. The center is associated with the University of Bonn and offers a stimulating research environment through its international network, workshops and conferences, data service, project support, research visits and doctoral program. IZA engages in (i) original and internationally competitive research in all fields of labor economics, (ii) development of policy concepts, and (iii) dissemination of research results and concepts to the interested public.
\end{abstract}

IZA Discussion Papers often represent preliminary work and are circulated to encourage discussion. Citation of such a paper should account for its provisional character. A revised version may be available directly from the author. 
IZA Discussion Paper No. 6118

November 2011

\section{ABSTRACT}

\section{Profit Sharing and Training*}

We analyze the impact of profit sharing on the share of workers receiving training. An effect is plausible because: 1) profit sharing is a credible commitment by firms to reward firmspecific skills acquired by formal or informal training, 2) profit sharing may reduce turnover and increase the returns to training, 3) a common payment for the whole workforce leads to peer group pressure to participate in training courses and raises incentives to help coworkers. In order to eliminate possible selectivity effects, we combine a matching approach with difference-in-differences. We identify the proportion of employees participating in profits and differentiate profit sharing according to the percentage of the workers covered by such remuneration schemes. Using German establishment data we find that profit sharing only has a significant effect on training intensity if the majority of the workforce benefits from it.

JEL Classification: $\quad$ C14, J33, M52, J24

Keywords: profit sharing, training, matching

Corresponding author:

Kornelius Kraft

TU Dortmund

Department of Economics, Business and Social Science

Vogelpothsweg 87

44221 Dortmund

Germany

E-mail: Kornelius.Kraft@tu-dortmund.de

* Financial support from the Deutsche Forschungsgemeinschaft (DFG) is gratefully acknowledged. The authors also thank the German Federal Employment Agency (BA) and the Institute for Employment Research (IAB) for providing the data. Any data or computational errors in this paper are our own. 


\section{Introduction}

For obvious reasons incentives are of utmost interest in economics and for many years economists have analyzed the application and effects of incentive payments. One variant of performance-linked remuneration is profit sharing. This group incentive scheme implies that a part of the compensation of (almost) all employees is variable and depends on the overall profits of the firm. A large number of empirical studies report the effects of profit sharing on company performance, where productivity, profitability, wages and employment are frequently analyzed. The reason most commonly suggested for the observed better performance is the incentive effect of a variable remuneration and, as profit sharing is a group incentive, peer group pressure to accord to somehow defined performance standards. Although this is probably the main reason for the frequently reported higher performance of organizations with a profit sharing system, there might also be indirect effects at work. The purpose of our study is to investigate the effect of profit sharing on training intensity as another possible cause of higher productivity.

Clearly, human capital is of prime importance not only for the productivity but also for the profitability of a company. The literature on human capital ${ }^{1}$ does not usually discuss the role of incentive payments like profit sharing. However, a collective incentive system may well affect investment in human capital. If a sharing system is employed, a return on investment costs is automatically guaranteed, as a binding arrangement regulates the use of profits. This is not always the case in a traditional wage system, as wages are largely determined by other factors such as seniority or favoritism of specific groups who have a particular bargaining power.

\footnotetext{
${ }^{1}$ Becker (1962, 1964) developed a framework for analyzing investment in and returns to specific and general qualifications. A survey of the theoretical literature is given by Leuven (2005) and a recent comparative empirical study was conducted by Arulampalam, Booth and Bryan (2004). Later contributions (Katz and Zidermann, 1990, Chang and Wang, 1996, Acemoglu and Pischke, 1999a,b, Stevens, 1994) considered market imperfections, such as asymmetric information and imperfect information, and modified Becker's conclusion on the financing of human capital investment.
} 
Profit sharing is an extreme form of group incentives, as the "group" consists of the whole workforce. Every member of the organization then has an interest in a high productivity of their co-workers and will encourage participation in training courses as any increase in productivity will benefit her/his own income. Furthermore, every member of the workforce has a self-interest in helping colleagues during training on-the-job.

As emphasized by many authors, profit sharing is expected to align interests of employers and employees. One consequence may be lower employee turnover. Moreover, if profit sharing is an add-on and not a substitute of the going wage rate, total remuneration will increase. This also has a negative impact on quits. Clearly, longer expected tenure positively affects the incentives to invest in firm-specific human capital. Hence, the training decision may be one cause of the frequently observed better performance of companies with a sharing system.

Despite the given relevance, the relation between profit sharing and training is rarely analyzed. The only papers of which we are aware are Azfar and Danninger (2001), Parent (2004) and Gielen (2007). The authors all apply information from household panels, whereas we use company data for our empirical analysis. Azfar and Danninger (2001) and Gielen (2007) emphasize the negative effect of profit sharing on turnover, which in turn increases expected tenure and raises incentives for investing in firm-specific human capital. Parent (2004) regards profit sharing as a credible commitment of firms to reward the acquisition of firm-specific skills.

Our contributions to this topic are the following ones: Firstly our data allow us to disaggregate the profit sharing variable. We differentiate between firms where only a small, medium or large share of all workers benefit from profit sharing. This appears to be important because the percentage of workers of an establishment covered by profit sharing varies enormously.

It is well known that in the absence of tax incentives or mandatory requirement only a minority of all firms use profit sharing. Given the overwhelming empirical evidence on the beneficial effects of profit sharing this seems to be paradoxical. As it is very unlikely that the 
majority of all firms behave irrationally over a longer period, we suppose that selectivity effects are at work. Either only some firms have specific advantages from using such a scheme or firms which introduce it are in general the more efficient ones. In both cases simple cross-sectional comparisons would overestimate the average effect for all firms. Therefore, we apply modern econometric methods to take into account selectivity effects. This is done with respect to observable as well as unobservable factors responsible for sample selectivity by applying matching and conditional difference-in-differences. We find that profit sharing increases the training intensity, but only if the majority of all workers participate in this incentive payment.

The paper is structured as follows. The next section contains a short theoretical discussion of the impact of profit sharing on training. Section 3 describes the econometric methodology used for our estimations. In Sections 4 and 5 we present our data and the results of the empirical analysis before we conclude in Section 6.

\section{Theoretical Considerations}

The relevance of human capital for the success of firms and the growth of economies is undisputed. Along with technical progress it determines productivity and the performance of companies. Reflecting its importance, human capital formation is an intensely investigated issue in economics; yet it is rarely discussed in connection with collective incentive systems. In particular the causal relation running from profit sharing to training is largely ignored ${ }^{2}$.

Many empirical studies have shown that firms which use incentive systems such as profit sharing are more successful, measured in terms of productivity and profitability. ${ }^{3}$ The superior

\footnotetext{
${ }^{2}$ The very interesting and innovative literature on human resource management policy deals with, among other things, both training and incentive payments, but not with any causal relationship between them. Many studies analyze, for example, how HRM practices affect productivity, and emphasize that complementarities among work practices can amplify a positive impact, but do not consider causal relations between the measures (see for example Huselid, 1995 or Ichniowski, Shaw and Prennushi, 1997).

${ }^{3}$ Studies analysing such effects of profit sharing are e.g. FitzRoy and Kraft (1987), Möller (2000), for Germany; Wadhwani and Wall (1990), Kruse (1992), Doucouliagos (1995), Cahuc and Dormont (1997), Blasi et al. (2008) with data from other countries.
} 
performance is usually explained by improved motivation of the workers, who increase their effort. Productivity is, however, also the result of the qualification of the employees, which tends to be ignored when the effects of incentive schemes are discussed.

Profit sharing is a group-based incentive payment and an alternative to purely individual wage payments. This also alters incentives concerning training. Becker $(1962,1964)$ has shown that costs for investment into firm-specific human capital have to be shared between the firm and the employee in order to avoid moral hazard problems. Profit sharing provides a credible commitment on the part of the firm to share all additional returns. Hence the moral hazard problem is at least mitigated.

Recent contributions, like Acemoglu and Pischke (1999a, b), demonstrate that a compressed wage structure implies incentives for the firm to invest in general employee training. There are several sources of wage compression. One reason for this is the existence of incomplete competition in the labor market, which implies that a skilled worker has few alternative employers at his or her disposal and the firm has some monopsony power. Hence, even if qualifications are general, the employee is unlikely to quit, although the wage is below her productivity. In this case it also pays for the company to invest in general human capital. Another reason could be information asymmetries, first suggested by Katz and Ziderman (1990) who argue that asymmetric information might play an important role in the context of general training. If potential employers are looking for new employees, they are less well informed about the skills a worker possesses than the current employer who trained this person. This reduces the advantages that a generally trained worker can gain by changing his or her job. If employees with general skills have no incentive to move to another firm, employers will (at least partly) pay for general training. But also if employers bear (part of) the cost for general training, employees must still be willing to participate in training courses. 
This will only be the case if workers can be sure that they will benefit from their training effort. $^{4}$

The idea of a collective incentive system is to provide a clear basis for sharing returns, which are jointly created by capital and labor. Any increase in performance is divided between the factors of production. Profit sharing systems are not usually abandoned by the company and have simple rules concerning the division of profits. Thus, profit sharing provides a credible commitment on the part of the firm to share all additional returns. Parent (2004) motivates the necessity for a commitment by the very nature of specific skills. These skills are worthless outside of the particular firm and therefore no market value exists. Hence, there are no market forces at work which would lead to an optimal sharing rule. By introducing profit sharing, it is fixed that workers get a share of the profits and they can be confident that they will not be held up after investing time and money in the acquisition of specific skills.

As more recent theoretical approaches suggest that firms also have an incentive to invest in the general skills of their workers, as in the case of specific training, it is not guaranteed that employees will get a fair share of the training benefits. Therefore, the positive effect of profit sharing as a binding commitment also applies with regard to general training.

Economists are sometimes surprised that profit sharing has any beneficial effects at all as the value of any productivity increase has to be shared with all other employees. However, obviously the worker in question has to bear alone the disutility from increased effort. This is called the $1 / \mathrm{N}$ (with $\mathrm{N}$ being the number of employees) or free rider problem. This problem is also present in the case of training investments. The return of any further education has to be shared with all the others in the firm. Hence, the pay-outs resemble a prisoner's dilemma, where joint cooperative action would lead to an improvement on individual cheating, but the highest pay-out is received only if all others play cooperatively (invest in human capital) but I do not. However, in contrast to the classical prisoner's dilemma the behavior of the other

\footnotetext{
${ }^{4}$ In the empirical section we use a variable concerning training participation, but we have no information as to whether such training courses impart specific or general knowledge.
} 
players is observed during the game and can be influenced by peer group pressure ${ }^{5}$. Furthermore, cooperation at work takes place every day and hence a repeated game would be much more appropriate to represent the situation than a one-shot prisoner’s dilemma. ${ }^{6}$

With a collective incentive payment every member of the group has a strong interest in a good performance by their co-workers. Hence, monitoring by a foreman is substituted or complemented by supervision on the same hierarchical level. This kind of supervision is probably very efficient and at the same time cost minimizing.

With regard to profit sharing, shared pay-outs imply that every member of the organization benefits from higher productivity of other members. It now pays to support on-the-job training of colleagues, since profit sharing creates a monetary reward for pushing co-workers to train more intensively. Perhaps even more important is that in such a situation it is in the interest of every employee to help others at the workplace. Hence, training-on-the-job will be intensified, become more efficient and most likely be much cheaper than if it is done by supervisors.

Additionally, profit sharing may have several effects on employee turnover. If paid on top of the going wage rate, profit sharing increases total remuneration ${ }^{7}$. As quits are partly determined by monetary factors, turnover will decline ${ }^{8}$. Work relations may also be affected as the intention of profit sharing is an alignment of interests of capital owners and workers. These factors in turn increase expected tenure and lead to a higher investment in specific human capital (see e.g. Azfar and Danninger, 2001). With a higher level of specific human capital the firm also reduces dismissals, as it wants to retain its investment ${ }^{9}$.

\footnotetext{
${ }^{5}$ For the effects of peer group pressure, see Kandel and Lazear (1992).

${ }^{6}$ High pressure on every co-worker to behave cooperatively will not be present if individual payment systems are employed and in tournaments we would just observe the contrary. Then sabotage would be rational.

${ }^{7}$ Kraft and Ugarkovic (2007) show that profit sharing is not a substitute for the usual wage rate.

${ }^{8}$ It is sometimes supposed that profit sharing is a substitute for the fixed wage and helps to stabilize employment over the business cycle by rendering remuneration more flexible. However, even if profit sharing is not a substitute for the going wage rate, but an add-on, it can be argued that its use will lead to more stable employment.

${ }^{9}$ If the firm finances general investment as well, the incentives to keep the employees are enhanced.
} 
Clearly, as an alternative to joint incentives, a working and flexible individual wage system could offer efficient rewards for any investment. However, not every firm has such an efficient wage system. Wages are frequently determined by bargaining with a union and then other factors besides efficiency, such as seniority or power of specific groups within the negotiating union, affect remuneration. Furthermore, efficient rewards require an exact identification of the productivity effects of training, which is in many cases rather difficult as only the aggregate output is observed. Performance evaluation is frequently subjective, leaving room for evaluators’ preferences, biases, discriminations and favoritism (Prendergast and Topel, 1993). This is all absent with binding arrangements as it is usually done in the case of profit sharing.

\section{Econometric Methodology}

In Western industrialized countries only a minority of all firms make use of the instrument of profit sharing. According to the statistics of the European Commission (Poutsma, 2001) the percentage of firms with a profit sharing system in the European Union is quite low except when tax or other incentives encourage the use of this payment method as it is the case in France and the United Kingdom (Table 1). ${ }^{10}$

Probably the majority of capital owners do behave rationally by not using profit sharing. Hence, there may be other reasons which inhibit apparently useful variable remuneration schemes. It is most likely that some firms have specific advantages in implementing them. There may be special conditions with respect to, for example, the work content (simple or demanding) or verification possibilities of the individual performance due to work organization (team versus individual tasks), that are responsible for the working of profit sharing. That means that firms with specific characteristics may use profit sharing, while

\footnotetext{
${ }^{10}$ Poutsma (2001) extensively discusses the country differences concerning financial participation in various member states of the European Union.
} 
others have no interest in such a kind of incentive and in contrast rely on other motivational instruments such as efficiency wages, tournaments or piece rates.

Table 1 - Incidence of profit sharing in selected countries

\begin{tabular}{lc}
\hline Country & Profit sharing establishments (\%) \\
\hline Denmark & 10 \\
France & 57 \\
Germany & 13 \\
Ireland & 8 \\
Italy & 5 \\
Netherlands & 14 \\
Portugal & 7 \\
Spain & 8 \\
Sweden & 20 \\
UK & 40 \\
\hline Source: Poutsma, 2001.
\end{tabular}

Hence, to analyze the effect of profit sharing on training, a mere comparison of firms with and without such a remuneration system is not appropriate. Different econometric approaches are suggested to account for factors that could affect a firm's probability to introduce profit sharing. One popular method to overcome the problem of selectivity in terms of observable factors is matching ${ }^{11}$. The idea of this method is to compare the outcome of a treated group with the outcome of a similar group without treatment, which substitutes the counterfactual outcome (the outcome of a firm with treatment if it was not treated). ${ }^{12}$ Additionally, in order to remove the influence of unobserved time-invariant characteristics, we use a conditional difference-in-differences estimation, which combines matching with a before-after comparison.

\footnotetext{
${ }^{11}$ We want to know if profit sharing can increase incentives for a firm to invest in human capital. Given that we are actually interested in this causal effect, a simple regression would clearly not be sufficient. If assignment to the treatment group is not random, selection bias in estimating the effect of profit sharing on training can occur because the error term and the treatment variable are correlated. We observe that the different treatment groups and the group of firms without profit sharing differ in many respects. Therefore, it is our view that assignment to treatment is unlikely to be random, selectivity is a problem and we try to control for it with our approach.

${ }^{12}$ Matching is mainly used to evaluate the effects of active labour market programs, see e.g. Lechner and Wunsch (2009) and Lechner, Miquel and Wunsch (forthcoming).
} 
A closer look at the proportion of the workforce which is covered by the sharing system reveals that in many cases only a small proportion of all employees participate in profit sharing. That could mean that incentive payments are only used for the top management. ${ }^{13} \mathrm{~A}$ variable and profit-related remuneration for the top management is also an incentive scheme, but it is very different from letting all employees of an establishment participate. Hence, it appears to be crucial to identify the share of workers who actually benefit from profit sharing. We divide our treatment group of profit sharing firms into three different dummy variables. The most important treatment in our analysis is profit sharing for the majority of the workers (PS=3), whereas $\mathrm{PS}=1$ represents establishments, where only a small percentage of the employees is covered by a profit related payment. All establishments with a coverage between the two corresponding threshold values fall in category PS=2 and firms without profit sharing are represented by PS=0.

The matching framework for binary treatments is extended to multiple treatments by Imbens (2000) and Lechner (2001, 2002a, b) ${ }^{14}$. Following Lechner's procedure there are $\mathrm{M}+1$ different treatments with outcomes $\mathrm{Y}^{0}, \mathrm{Y}^{1}, \ldots, \mathrm{Y}^{\mathrm{M}}$. For each treatment $\mathrm{m}$ only $\mathrm{Y}^{\mathrm{m}}$ can be observed and all other outcomes are counterfactuals. In the case of multiple treatments each group can be used as treatment as well as comparison group. The average treatment effect of treatment $\mathrm{m}$ relative to treatment $\mathrm{l}$ is

$$
E\left(Y^{m}-Y^{1} \mid P S=m\right)=E\left(Y^{m} \mid P S=m\right)-E\left(Y^{1} \mid P S=m\right)
$$

\footnotetext{
${ }^{13}$ Unfortunately, the data we use provides no information on which type of employees (e.g. with respect to their occupational position) benefits from profit sharing in a specific firm.

${ }^{14}$ Matching for multiple or continuous treatments has mainly been applied before to the evaluation of active labor market policy programs. Lechner, Miquel and Wunsch (2007), for example, use this method to distinguish between different training programs for the unemployed and their effects on the outcomes of interest. The multiple treatment approach is less often applied to other topics. One exception is Görg, Henry and Strobl (2008) who investigate the effects of government support on exporting activity by distinguishing between small, medium and large subsidies. They also combine multiple treatment matching with difference-in-differences.
} 
$\mathrm{E}\left(\mathrm{Y}^{\mathrm{l}} \mid \mathrm{PS}=\mathrm{m}\right)$ stands for the counterfactual outcome. By definition, the counterfactual outcome is not observable since it describes the hypothetical outcome of not using profit sharing (or having a different level PS=l of profit sharing) in a company which in fact applies a specific level of profit sharing (PS=m). Therefore, a comparable counterpart for every treated firm must be found among the group of firms without or with another treatment. If the treatment status was considered as randomly assigned, the average outcome of firms with treatment 1 $\mathrm{E}\left(\mathrm{Y}^{\mathrm{l}} \mid \mathrm{PS}=\mathrm{l}\right)$ could serve as an estimator for $\mathrm{E}\left(\mathrm{Y}^{\mathrm{l}} \mid \mathrm{PS}=\mathrm{m}\right)$. Without random assignment the problem in equation (1) could be solved if the characteristics which promote the establishment's decision to apply profit sharing for a certain proportion of the workforce can be determined. For these purposes Rubin (1977) introduced the conditional independence assumption (CIA) for binary treatments. Lechner (2001) shows that the CIA can be redefined for multiple treatments. The CIA states that the potential outcomes $\mathrm{Y}^{\mathrm{l}}$ and $\mathrm{Y}^{\mathrm{m}}$ are independent of the treatment status PS for firms with the same observable characteristics X:

$$
\mathrm{Y}^{\mathrm{m}}, \mathrm{Y}^{\mathrm{l}} \perp \mathrm{PS} \mid \mathrm{X}
$$

We use propensity score matching proposed by Rosenbaum and Rubin (1983) to overcome the high dimensionality problem caused by the large number of determinants of profit sharing $\mathrm{X}$. The propensity score is a function of the vector $\mathrm{X}$ and describes the propensity of introducing a certain level of profit sharing. Now firms with similar propensity scores are matched. Different matching estimators are possible. We use nearest neighbor matching ${ }^{15}$ with replacement ${ }^{16}$.

\footnotetext{
${ }^{15}$ More precisely, we use nearest neighbor matching with two neighbors as this improves the matching quality compared to the case where we only use one nearest neighbor. In addition to nearest neighbor matching we also tried other matching methods, e.g. kernel matching, which leads to similar results.

${ }^{16}$ Matching with replacement allows the observations of the control group to serve for different matches. It avoids the problem that treated and control units with different probabilities must be matched if there are only few similar comparison units. The disadvantage of matching with replacement is a higher variance due to the smaller number of control units used (Dehejia and Wahba, 2002).
} 
However, unobservable factors might also influence the impact of profit sharing. To additionally control for these factors the conditional difference-in-differences approach is appropriate. It combines the advantages of non-parametric matching and a difference-indifferences comparison. Just like in the first case, where we look at the existence of different profit sharing intensities in 2009, we also estimate treatment effects for multiple treatments when analyzing the implementation of profit sharing between 2007 and 2009. Using the difference-in-differences estimator, the average treatment effect of treatment $\mathrm{m}$ relative to treatment $\mathrm{l}$ is the difference between the change in the outcome of firms with treatment $\mathrm{m}$ and those with treatment $\mathrm{m}$ during the considered period:

$$
E\left(Y_{t 1}^{m}-Y_{t 0}^{m}\right)-E\left(Y_{t 1}^{1}-Y_{t 0}^{1}\right)
$$

To control for observable as well as unobservable heterogeneity, the conditional differencein-differences approach compares the difference of the changes of outcomes of treated and matched firms without treatment or with another treatment. Therefore, the second part of equation (3) is replaced by the difference in the outcome of matched establishments.

Difference-in-differences controls for common time trends and permanent differences between the two groups considered. A crucial assumption for difference-in-differences to be valid is that firms with and without profit sharing do not seriously change in their unobserved characteristics over time (see e.g. Blundell and Costa Dias, 2009). Even though we do not know whether this assumption holds, we view the combination of matching and difference-indifferences as the best possible method currently available to deal with observable and unobservable heterogeneity. As our observation period is not very long, we can be quite optimistic that there are no serious changes in the relevant variables over time. ${ }^{17}$

\footnotetext{
${ }^{17}$ What exactly is the value added of this methodology over simple linear regression? In a cross-sectional framework, linear regression will not shed light on the impact of an introduction of profit sharing. This is,
} 
To sum up, our approach is the following: We distinguish between different levels of profit sharing intensity and analyze the effects of these different levels. First we analyze the existence of a certain profit sharing intensity in 2009. We compare the outcomes of the three different profit sharing levels $(m=1,2,3)$ with the outcome of firms without profit sharing. Afterwards we consider the introduction of profit sharing between 2007 and 2009. Therefore, we use a second sample and can additionally control for unobservable differences between the treatment and the control groups by combining matching with difference-in-differences (conditional difference-in-differences).

In order to compute the propensity scores we specify multinomial logit models. Although the endogenous variable is based on the percentage of employees with profit sharing, we do not treat it as an ordered but as an unordered variable model. In our sample the majority of establishments with profit sharing offer it either to almost all or to a very small share of employees. We prefer the multinomial over the ordered logit model, because there appear to be different motives at work, if an establishment introduces a profit sharing scheme for all workers or applies it only to a minority.

As an alternative to multinomial logit or probit models Lechner (2001, 2002a, b) suggests the estimation of binary choice models for each subsample of firms with treatments $\mathrm{m}$ and $\mathrm{l}$ (or without treatment) for all different combinations of treatments. As a robustness test, we

however, the main contribution of difference-in-differences. The general advantages of matching over linear regression analysis are that the former is non-parametric and it imposes the common support assumption. In the absence of common support the model needs to be extrapolated over unobservable regions of the distribution of the right-hand variables. Clearly, the common support assumption could also be imposed within the linear regression framework, but "Most frequently, researchers seem unaware that a common support problem exists" (Blundell and Costa Dias 2009, 599). Furthermore, it is well known that in a regression framework any possible endogenous relations running from training to the right-hand side variables would bias all coefficients. As shown by Frölich (2008), a nonparametric matching estimator permits endogenous control variables, as long as profitsharing does not determine the control variables. The reason for this result is that nonparametric matching compares only observations which have the same values for the control variables and differ only in the treatment variable, whereas parametric regression combines all observations in a single regression.

Heckman et al. (1998) show that possible bias from ignoring selectivity comes from three sources: 1) neglect of common support 2) observed heterogeneity 3) unobserved heterogeneity. Conditional difference-in-differences takes account of all three factors while linear regression only considers observed heterogeneity. Smith and Todd (2005) point to the relevance of difference-in-differences in addition to matching in establishing robustness of the results. 
additionally follow this approach, both for existence and introduction of different profit sharing levels.

\section{Data and Descriptive Statistics}

For our estimations we use the German IAB Establishment Panel of the Institute for Employment Research of the German Federal Employment Agency. It is a representative survey of German establishments employing at least one employee covered by social insurance. Data have been collected annually since 1993. The IAB Establishment Panel was extended to cover East German establishments in 1998. Since 2001 more than 15000 establishments have been observed every year. The IAB Establishment Panel provides detailed information on many labor market topics. The main part of the questionnaire is identical every year. The panel includes annual information about general topics like turnover, the number of employees and wages. But there are also questions which are only posed irregularly. Data on the number of participants in training are available for nine waves of the survey ${ }^{18}$. Training intensity is computed by dividing the number of persons taking part in training in the first six months of the year by the total number of employees. Data on profit sharing are provided for 1998, 2000, 2001, 2005, 2007 and 2009. Along with the question of whether the establishment offers profit sharing at all, in 2000, 2001, 2005 and 2009 the question is also asked which proportion of employees benefits from it. We use this information to construct our treatment variables for the multiple treatment approach.

We use two different samples for our estimations. Regarding the existence of profit sharing as treatment variable we use data for 2009 and construct our first sample. It consists of 4742

\footnotetext{
${ }^{18}$ More precisely, training information is available for the waves 1993, 1997, 1999, 2001, 2003, 2005, 2007, 2008 and 2009.
} 
non-treated and 1075 profit sharing firms, with 1067 of them also reporting the share of employees involved in profit sharing ${ }^{19}$.

For the 1067 firms with information on profit sharing intensity, Figure 1 presents the distribution of the proportion of employees whose remuneration partly depends on a firm's performance. It is obvious that the mere existence of profit sharing does not imply that it is applied to the whole workforce. On the one hand in more than 40 percent of all profit sharing establishments, all employees of the firm participate. On the other hand in one third of all profit sharing firms, less than 20 percent of the workforce is covered by profit sharing.

Figure 1 - Distribution of profit sharing intensity in profit sharing establishments (2009)

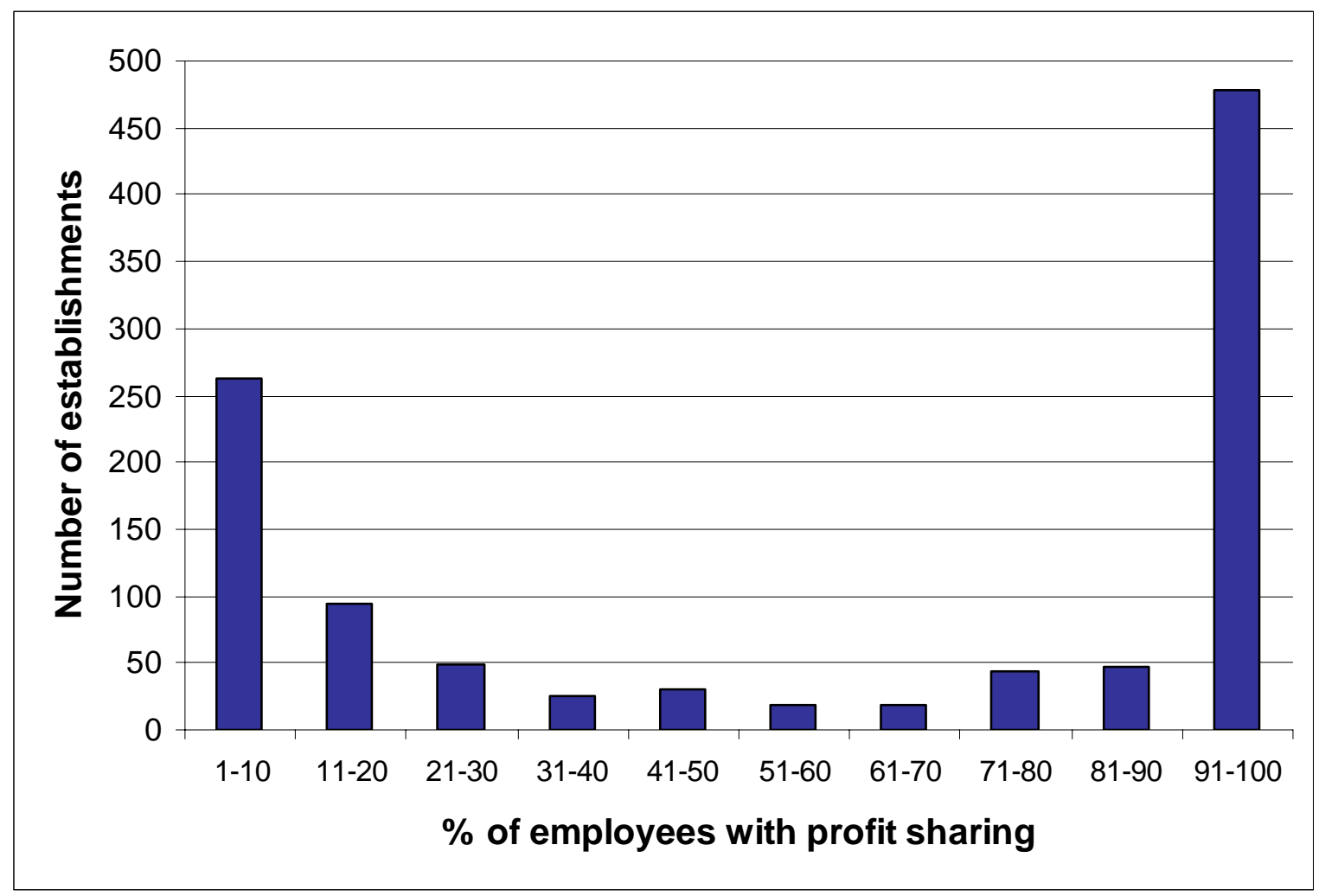

Source: IAB Establishment Panel, wave 2009, own calculations (controlled remote data access via FDZ).

These figures indicate that responding firms and researchers may interpret the question differently. The literature on profit sharing usually assumes that all or at least most of the employees of an establishment receive, besides a fixed wage, a variable profit-related part,

\footnotetext{
${ }^{19}$ We only consider establishments with at least 5 employees for our analysis. Furthermore we exclude nonprofit firms and establishments from the forestry, agriculture and fisheries sector.
} 
whereas in practice almost half of the profit sharing firms in our sample only let a minority of their workforce participate. In such cases it is quite likely that profit sharing applies only to the top management. The impact of such a variable remuneration system for the top management is also an interesting and much discussed issue ${ }^{20}$, but it has nothing to do with the common notion of profit sharing. Hence, we focus on establishments with a high ratio of employees participating in profit sharing. For this purpose we divide establishments with profit sharing and distinguish between three treatments. In our first sample, where we consider the existence of a profit sharing scheme in 2009, treatment PS=1 is defined as profit sharing for less than $20 \%$ of all employees. The second treatment PS=2 represents profit sharing for at least $20 \%$ up to $99 \%$ of the workforce and PS=3 for all workers.

For our second sample, where we look at the introduction of profit sharing between 2007 and 2009, we identify all establishments which do not have a profit sharing system in 2007. The treatment observations are defined as those firms which introduced profit sharing between 2007 and 2009, whereas the control group consists of all firms without profit sharing throughout this period. We obtain a sample of 333 establishments which introduced profit sharing (four of these do not report profit sharing intensity) and 3670 firms without such a remuneration scheme. One third of the establishments introducing profit sharing offer it to at most 10 percent and one third to more than 95 percent of their workers. Hence, we define treatment PS=1 as profit sharing for less than $10 \%$ of all employees, the second treatment PS $=2$ as profit sharing for at least $10 \%$ up to $95 \%$ of the workforce and PS=3 as profit sharing for $96 \%$ or more. ${ }^{21}$

\footnotetext{
${ }^{20}$ Representative references include Jensen and Murphy (1990) and Hall and Liebmann (1998).

${ }^{21}$ We also tried different classifications for our samples (e.g. dividing the data into just two groups), which leads to similar results. Nevertheless, based on the bimodal distribution of profit sharing intensity it is reasonable to construct two different treatment groups which include the firms around the two peaks of the distribution and to put the remaining observations into a third group. Firms with intermediate profit sharing intensity appear to be different from the firms with low or high intensity (e.g. these firms are much smaller) and therefore we think we should not put them in the same group with one of the other two treatments.
} 
In our first sample only about 18.5 percent of all establishments use a profit sharing system in 2009 and in the second sample about 8.3 percent of those without profit sharing in 2007 introduce it by 2009. Not even half of those can be seen as profit sharing firms in the “classical” sense as they offer it to only a small proportion of the workforce. Therefore, different selectivity effects could render a simple comparison of treated and non-treated firms invalid.

Hence, we match firms with different coverage levels and without profit sharing with regard to the determinants of this financial incentive scheme. In the literature a number of variables are discussed which may affect the application of a sharing system for the workforce (see e.g. OECD, 1995, Pendleton et al., 2003). The following results for the mean values relate to the second sample which considers the introduction of profit sharing ${ }^{22}$.

Table 2 presents the mean values of all relevant variables for establishments which introduce or never use profit sharing between 2009 and 2007 as well as the mean values for the three different levels of multiple treatments at the beginning of the treatment period in 2007 (only the difference of the training intensity is measured as the difference between 2007 and 2009). A comparison of the mean values of the change in the share of trained persons between 2009 and 2007 confirms our basic hypothesis. In firms which introduced profit sharing between 2007 and 2009, the share of employees taking part in training increased from the first half of 2007 to the first half of 2009 by 7 percentage points which is significantly higher than the respective value of 1.5 percentage points in firms without a profit sharing system. However, a significant increase in the training intensity can only be found if a large proportion of employees participate in the sharing. Compared to establishments without profit sharing, firms with profit sharing for the majority of workers (PS=3) realize a higher difference in training intensity of 10 percentage points.

\footnotetext{
${ }^{22}$ The mean values for firms with and without profit sharing and the different profit sharing intensities for the first sample (existence of profit sharing in 2009) can be found in Table A1 in the Appendix.
} 
Table 2 - Mean values of profit sharing and non-profit sharing firms in 2007

\begin{tabular}{|c|c|c|c|c|c|}
\hline Variable & $\begin{array}{l}\text { Firms without } \\
\text { profit sharing } \\
\text { (PS }=0)\end{array}$ & $\begin{array}{l}\text { All firms with } \\
\text { profit sharing }\end{array}$ & $\begin{array}{c}\text { Firms with } \\
\text { profit sharing } \\
\text { for less than } \\
10 \% \text { of } \\
\text { employees } \\
(P S=1) \\
\end{array}$ & $\begin{array}{l}\text { Firms with } \\
\text { profit sharing } \\
\text { for } 10 \%-95 \% \\
\text { of employees } \\
(P S=2)\end{array}$ & $\begin{array}{c}\text { Firms with } \\
\text { profit sharing } \\
\text { for } 96 \%- \\
100 \% \text { of } \\
\text { employees } \\
\text { (PS=3) }\end{array}$ \\
\hline $\begin{array}{l}\text { Difference of training intensity } \\
\text { between } 2009 \text { and } 2007\end{array}$ & 0.015 & $0.070 * * *$ & 0.052 & 0.040 & $0.115^{* * *}$ \\
\hline Establishment size $<20$ & 0.540 & $0.291^{* * *}$ & $0.037 * * *$ & $0.401 * * *$ & $0.346 * * *$ \\
\hline Establishment size 20-49 & 0.210 & $0.267 * *$ & 0.268 & $0.292 * *$ & 0.227 \\
\hline Establishment size 50-249 & 0.203 & $0.318 * * *$ & $0.439 * * *$ & 0.234 & $0.336 * * *$ \\
\hline Establishment size 250-499 & 0.031 & $0.075^{* * *}$ & $0.182^{* * *}$ & 0.0437 & 0.036 \\
\hline Establishment size 500+ & 0.018 & $0.048 * * *$ & $0.073^{* * *}$ & 0.029 & $0.055^{* * *}$ \\
\hline Number of employees & 60.597 & $126.664 * * *$ & $180.671^{* * *}$ & 76.591 & $152.082^{* * *}$ \\
\hline Shift responsibilities (dummy) & 0.118 & $0.201 * * *$ & $0.183^{*}$ & $0.182^{* *}$ & $0.236 * * *$ \\
\hline Teamwork (dummy) & 0.063 & $0.135^{* * *}$ & $0.146 * * *$ & $0,124 * * *$ & $0.136^{* * *}$ \\
\hline $\begin{array}{l}\text { Independent work groups } \\
\text { (dummy) }\end{array}$ & 0.045 & $0.108 * * *$ & $0.146^{* * * *}$ & $0,086 * *$ & $0.100 * * *$ \\
\hline $\begin{array}{l}\text { Share qualified employees } \\
\text { (percent) }\end{array}$ & 0.057 & $0.107 * * *$ & 0.072 & $0.126^{* * *}$ & $0.112^{* * *}$ \\
\hline Collective bargaining (dummy) & 0.434 & 0.423 & $0.561^{* *}$ & 0.409 & $0.336^{* *}$ \\
\hline Works council (dummy) & 0.185 & $0.348 * * *$ & $0.488 * * *$ & $0.263^{* *}$ & $0.364 * * *$ \\
\hline Export share & 0.059 & $0.127 * * *$ & $0.133^{* * *}$ & $0.110^{* * *}$ & $0.141^{* * *}$ \\
\hline ICT investment (dummy) & 0.442 & $0.646^{* * *}$ & $0.695 * * *$ & $0.606^{* * *}$ & $0.655^{* * *}$ \\
\hline $\begin{array}{l}\text { Limited liability (dummy=1 if } \\
\text { AG, GmbH) }\end{array}$ & 0.599 & $0.820 * * *$ & $0.927 * * *$ & $0.737 * * *$ & $0.836 * * *$ \\
\hline $\begin{array}{l}\text { Age (dummy=1 if founded after } \\
\text { 1990) }\end{array}$ & 0.518 & 0.484 & 0.463 & $0.438 *$ & 0.536 \\
\hline $\begin{array}{l}\text { East German establishment } \\
\text { (dummy) }\end{array}$ & 0.429 & 0.393 & 0.341 & 0.394 & 0.436 \\
\hline $\mathrm{N}$ & 3670 & 333 & 82 & 137 & 110 \\
\hline
\end{tabular}

Turning to the variables which may determine the use of profit sharing, we concentrate on comparing firms without a sharing system with those establishments which let at least $96 \%$ of their employees participate. The size of a firm could have both positive and negative effects on the probability to introduce profit sharing. Larger firms may bear the costs of the introduction of a new remuneration system more easily. Furthermore, the more employees, the more difficult it becomes to monitor them and problems of asymmetric information become more severe. If a profit sharing scheme is applied, aims of the employer should become aligned with those of the workers, which may cause them to monitor each other. On 
the other hand the free rider problem is more severe for larger firms. Firms with a high percentage of profit sharing and those without differ significantly in size. Treated firms (PS=3) have 152 whereas the non-treated ones only have 61 employees on average. For our estimations size is considered by five different size categories (dummy variables for firms with 5-19, 20-49, 50-249, 250-499 and at least 500 employees).

As mentioned above, Human Resources literature suggests that monetary incentives come along with other HRM practices. All these measures are expected to be more common in establishments whose work organization is very complex and where individual output is difficult to observe. Hence we include dummies for different HRM measures: the shift of responsibilities, teamwork and independent work groups in our estimations ${ }^{23}$. Firms which employ sharing systems are also expected to be characterized by a large share of qualified employees and by a high investment in information and communication technology. Table 2 supports these suggestions. All variables mentioned above are significantly different for nontreated and treated firms if treatment three is considered. These profit sharing firms have a considerably higher share of qualified workers and invest more in information and communication technology (ICT). In addition, they more often implement forms of nonmonetary incentives. Employee participation is seen as another important factor with regard to profit sharing. Profit sharing is easier to implement in a consultative environment where the level of trust between employees and management is high. We use the existence of a works council to control for a cooperative climate ${ }^{24}$. The existence of a works council could also help to introduce a sharing system as then management could easily talk with a representative body about the exact design of the system. By contrast, the impact of unions on profit sharing is not clear. Workers whose earnings partly depend on the firm's performance are supposed to be more strongly affiliated with their employer and less with workers' representation

\footnotetext{
${ }^{23}$ Employers are asked if these HRM practices were introduced during the last three years.

${ }^{24}$ One could also argue that the existence of a works council stands for the contrary situation, where the workforce is in need of a representative body, as industrial relations are controversial.
} 
organizations like unions. The casual observation that unions have been rather hostile towards profit sharing systems supports this presumption. However, if profit sharing is paid in addition to the base wage, as is documented in a number of empirical studies (see e.g. Wadhwani and Wall, 1990, Bhargava and Jenkinson, 1995, Kraft and Ugarkovic, 2007), there is at least no financial reason for unions to oppose this kind of remuneration system. We use a dummy variable which equals one if a firm is covered by a collective bargaining agreement. In our sample not only the share of firms with a works council is significantly higher among those with profit sharing for most of the workers, but also the share of firms with a collective agreement.

Introducing a flexible remuneration system may be especially valuable for firms whose profits are risky and show a high variance because they could transfer parts of the risk to the employees. Hence we include the export share of firms which is significantly higher for profit-sharing establishments. It is suggested that the frequency of profit sharing is higher in young and growing companies (dummy variable "age”, which equals one if an establishment is founded after 1990) which, however, is not supported by our simple comparison of means. Moreover, Möller (2000) finds that firms located in East Germany are less likely to introduce profit sharing, which cannot be confirmed from our analysis. Finally, we expect profit sharing more likely to be introduced in companies with limited liability, i.e. joint stock companies (AG) and non-public limited liability companies $(\mathrm{GmbH})$, which is true for firms in our sample. Looking at establishments reporting to offer profit sharing to a small percentage of employees (PS=1), these firms do not have more qualified workers than the reference group of firms without sharing (but the other sharing firms have).

The comparison of the mean values of the considered determinants points to the relevance of selectivity effects. Profit sharing firms are very different from those without this payment scheme and in general seem to be the better managed ones. These differences point to strong selectivity and therefore we think a method to take account of it is needed. 


\section{Estimation Results}

\section{Existence of profit sharing}

At first, we present the estimations for the matching approach, where we look at the existence of different profit sharing levels in 2009 and do not control for unobservable differences yet.

Table 3 reports the results of the multinomial logit estimation we need to calculate the propensity scores.

Table 3 - Results of multinomial logistic regression (existence of profit sharing)

\begin{tabular}{lccc}
\hline Variables & PS=1 & PS=2 & PS=3 \\
\hline Establishment size 20-491 & $1.493^{* * *}$ & $0.492^{* * *}$ & 0.268 \\
Establishment size 50-249 & $2.080^{* * *}$ & $0.428^{* *}$ & $0.464^{* * *}$ \\
Establishment size 250-499 & $2.527^{* * *}$ & $0.927^{* * *}$ & 0.340 \\
Establishment size 500+ & $2.631^{* * *}$ & $1.064^{* * *}$ & $1.066^{* * *}$ \\
Export share & -0.000 & $0.754^{* *}$ & $0.657^{* *}$ \\
Share of qualified employees & $1.057^{* *}$ & $0.977^{* *}$ & $1.574^{* * *}$ \\
Collective bargaining & 0.004 & $-0.466^{* * *}$ & 0.017 \\
Works council & 0.109 & $0.306^{*}$ & $0.967^{* * *}$ \\
Limited liability & $0.934^{* * *}$ & $0.379^{* *}$ & $0.897^{* * *}$ \\
Age & 0.197 & -0.134 & 0.192 \\
East German establishment & $-0.305^{* *}$ & -0.088 & 0.116 \\
Shift of responsibilities & $0.313^{* *}$ & $0.478^{* * *}$ & $0.401^{* * *}$ \\
Teamwork & $0.369^{* *}$ & 0.183 & -0.106 \\
Independent work groups & $0.353^{*}$ & 0.168 & 0.124 \\
ICT investment & $0.390^{* * *}$ & $0.386^{* * *}$ & $0.677^{* * *}$ \\
\hline Number of observations & 5809 & & \\
Pseudo R2 & 0.169 & & \\
$* * * * * * *$ indicates statistical significance at the 1\%, 5\% and 10\% level. & & \\
Note: Industry dummies are included in the analysis but are not reported. & & \\
${ }^{1}$ Reference group: firms with 5 to 19 employees. & & \\
Source: IAB Establishment Panel, wave 2009, own calculations (controlled remote data access via FDZ). & \\
\hline
\end{tabular}

We find that most variables have the expected effects but the impact of several variables depends on the coverage level. Larger firms are more likely to use profit sharing, but the size effect appears to be more pronounced for establishments with a low or medium coverage level. The higher the export share of a firm, the more often it applies profit sharing to a medium proportion of employees or to all workers ( $\mathrm{PS}=2$ or $\mathrm{PS}=3$ ), whereas firms with a low coverage (PS=1) are less often located in East Germany and are more likely to apply 
teamwork or independent work groups. Works councils seem to play an important role especially for profit sharing firms where all employees participate in the sharing system (PS=3).

As a robustness check we additionally specify probit models for the subsamples of firms with each treatment $\mathrm{m}$ and firms without profit sharing (and drop all firms with other treatments $\mathrm{l}$ ). The results of the probit estimations are reported in Table A2 in the Appendix. We now use the results of the probit and the multinomial logit estimations to calculate the propensity scores we use for our matching procedure. In order to check if our nearest neighbor matching was successful, a comparison of the mean values of the exogenous variables after matching is required. After matching the differences in the means of the relevant variables between firms without profit sharing and those with different profit sharing intensities are strongly reduced and there is no longer any significant difference (see Tables A3 and A4 in the Appendix). Hence, all our empirical results support the conclusion that selectivity effects are present. Table 4 shows the results of matching for the multiple treatments. ${ }^{25}$ Our estimation results reveal that establishments provide only significantly more training if profit sharing affects at least 20 percent of their employees regardless of whether we use multinomial logit or binary probit models to obtain the propensity scores ${ }^{26}$ Firms with a medium or high coverage level of profit sharing have a higher training intensity of more than 9 percentage points compared to matched firms without profit sharing. ${ }^{27}$

\footnotetext{
${ }^{25}$ We included the common support restriction, the importance of which is stressed by Heckman et al. (1998). Matching is only successful in the range of common support of profit sharing and non-profit sharing firms.

${ }^{26}$ We also estimated average treatment effects for binary treatments, where we only consider the existence or introduction of profit sharing, regardless of the percentage of workers covered. The average treatment effects after matching and conditional difference-in-differences for these binary treatments can be found in Table A5 in the Appendix. We find a positive effect on all treated establishments but, as can be seen in Table 4, this effect is driven by those firms which let at least $20 \%$ of the workers participate in the profits.

${ }^{27}$ Other matching methods, such as kernel matching, lead to almost the same results as nearest neighbor matching. The magnitude of the treatment effect changes only slightly and the significance remains the same. Thus, our matching results are robust.
} 
Table 4 - Estimation results matching $2009^{28}$

\begin{tabular}{|c|c|c|}
\hline Treatment group & Matched firms without profit sharing & Training difference \\
\hline \multicolumn{3}{|c|}{ Multiple treatments (after multinomial logit) } \\
\hline $\mathrm{PS}=1(<20 \%$ of employees $) \quad \mathrm{N}=312$ & $\mathrm{~N}=4742$ & \multirow{2}{*}{0.022} \\
\hline Training intensity: $\mathbf{0 . 2 5 3}$ & Training intensity: $\mathbf{0 . 2 3 2}$ & \\
\hline$P S=2(20 \%-99 \%$ of employees) $N=312$ & $\mathrm{N}=4742$ & \multirow{2}{*}{$0.099 * * *$} \\
\hline Training intensity: $\mathbf{0 . 3 7 7}$ & Training intensity: $\mathbf{0 . 2 7 8}$ & \\
\hline $\mathrm{PS}=3$ ( $100 \% \%$ of employees) $\mathrm{N}=443$ & $\mathrm{~N}=4742$ & \multirow{2}{*}{$0.094 * * *$} \\
\hline Training intensity: $\mathbf{0 . 3 7 0}$ & Training intensity: $\mathbf{0 . 2 7 6}$ & \\
\hline \multicolumn{3}{|l|}{ Multiple treatments (after binary probits) } \\
\hline $\mathrm{PS}=1(<20 \%$ of employees $) \quad \mathrm{N}=312$ & $\mathrm{~N}=4697$ & \multirow{2}{*}{0.011} \\
\hline Training intensity: $\mathbf{0 . 2 5 3}$ & Training intensity: $\mathbf{0 . 2 4 2}$ & \\
\hline PS=2 (20\%-99\% of employees) & $\mathrm{N}=4731$ & \multirow{2}{*}{$0.092 * * *$} \\
\hline Training intensity: $\mathbf{0 . 3 7 7}$ & Training intensity: $\mathbf{0 . 2 8 4}$ & \\
\hline PS $=3$ ( $100 \% \%$ of employees) $\mathrm{N}=443$ & $\mathrm{~N}=4742$ & \multirow{2}{*}{$0.097 * * *$} \\
\hline Training intensity: $\mathbf{0 . 3 7 0}$ & Training intensity: $\mathbf{0 . 3 7 7}$ & \\
\hline
\end{tabular}

$* * * / * * / *$ indicates statistical significance at the $1 \%, 5 \%$ and $10 \%$ level.

Source: IAB Establishment Panel, wave 2009, own calculations (controlled remote data access via FDZ).

Note: Industry dummies are included in the analysis but are not reported.

\section{Introduction of profit sharing}

After the matching analysis we now present the results for the treatment "introduction of profit sharing” where we additionally control for unobservable differences. Therefore, we again require a multinomial logit model to estimate the propensity scores. ${ }^{29}$ We divide the firms which introduce profit sharing as explained in Section 3.

The results for the introduction of profit sharing presented in Table 5 indicate that, in particular, representation of the employees' interests by a works council and the share of qualified employees have strong effects on the introduction of profit sharing for the majority of workers (PS=3). Furthermore, the dummy variable indicating export share is only significant in the case of medium coverage. In contrast, firm size appears to be relevant concerning the decision to introduce profit sharing if only a minority of employees is covered (probably the senior management). This last result is quite plausible, as with increasing firm size control problems and asymmetric information gain relevance. Our matching procedure

\footnotetext{
${ }^{28}$ In some cases we lose some observations due to the common support restriction. Another reason for differing numbers of observations is that in some cases one of the industry dummies causes perfectly predicted failure.

${ }^{29}$ In addition to a multinomial logit model we again estimate binary probit models. The estimation results can be found in Table A6 in the Appendix.
} 
works as no significant differences exist any longer in the mean values between treated and matched control firms. ${ }^{30}$

Table 5 - Results of multinomial logistic regression (introduction of profit sharing)

\begin{tabular}{lccc}
\hline Variables & PS=1 & PS=2 & PS=3 \\
\hline Establishment size 20-49 & $2.632^{* * *}$ & $0.479^{* *}$ & 0.012 \\
Establishment size 50-249 & $3.049^{* * *}$ & 0.198 & 0.077 \\
Establishment size 250-499 & $3.972^{* * *}$ & 0.155 & -0.504 \\
Establishment size 500+ & $3.712^{* * *}$ & 0.461 & 0.424 \\
Export share & 0.109 & $0.908^{* *}$ & 0.687 \\
Share of qualified employees & -0.139 & $1.594^{* * *}$ & $1.186^{*}$ \\
Collective bargaining & -0.010 & -0.154 & $-0.617^{* *}$ \\
Works council & 0.274 & 0.293 & $0.666^{* *}$ \\
Limited liability & $0.888^{*}$ & 0.346 & $0.743^{* *}$ \\
Age & 0.149 & $-0.455^{* *}$ & 0.081 \\
East German establishment & -0.179 & 0.097 & -0.089 \\
Shift of responsibilities & -0.092 & 0.190 & 0.407 \\
Teamwork & 0.300 & 0.351 & 0.244 \\
Independent work groups & 0.519 & 0.250 & 0.342 \\
ICT investment & 0.325 & $0.335^{*}$ & $0.480^{* *}$ \\
\hline Number of observations & 3999 & & \\
Pseudo R2 & 0.140 & & \\
\hline
\end{tabular}

$* * * / * * * *$ indicates statistical significance at the $1 \%, 5 \%$ and $10 \%$ level.

Source: IAB Establishment Panel, waves 2007-2009, own calculations (controlled remote data access via FDZ).

Note: Industry dummies are included in the analysis but are not reported.

${ }^{1}$ Reference group: firms with 5 to 19 employees.

Table 6 presents the results of conditional difference-in-differences. It turns out that, just like in the case for existence of profit sharing, the effects of profit sharing depend on the share of workers covered. ${ }^{31}$ When unobservable heterogeneity is taken into account the result is confirmed that profit sharing for a small share of employees (maybe only for managers) has no effect on training. Only firms which introduce profit sharing for the majority of the

\footnotetext{
${ }^{30}$ The differences in the means between treated and matched firms are reported in Tables A7 and A8 in the Appendix.

${ }^{31}$ If we only consider a binary treatment, the results indicate that firms which introduce profit sharing have a significantly higher training intensity compared to firms without profit sharing (see Table A5 in the Appendix). However, taking different coverage levels into account, we find that this overall effect is only caused by firms with high profit sharing intensity.
} 
workforce show a significant rise in the training intensity. ${ }^{32}$ Depending on whether a multinomial logit model or binary probit estimations are used to obtain the propensity scores, the positive training effect is 8.2 and 11.6 percentage points respectively. ${ }^{33}$

Table 6 - Estimation results conditional difference-in differences 2007-2009 ${ }^{34}$

\begin{tabular}{|c|c|c|}
\hline Treatment group & Matched firms without profit sharing & Training difference \\
\hline \multicolumn{3}{|c|}{ Multiple treatments (after multinomial logit) } \\
\hline $\mathrm{PS}=1(<20 \%$ of employees $) \quad \mathrm{N}=82$ & $\mathrm{~N}=3670$ & \multirow{2}{*}{0.046} \\
\hline Training difference: $\mathbf{0 . 0 5 2}$ & Training difference: $\mathbf{0 . 0 0 6}$ & \\
\hline $\mathrm{PS}=2(20 \%-99 \%$ of employees) $\mathrm{N}=135$ & $\mathrm{N}=3670$ & \multirow{2}{*}{0.033} \\
\hline Training difference: $\mathbf{0 . 0 3 6}$ & Training difference: $\mathbf{0 . 0 0 3}$ & \\
\hline $\mathrm{PS}=3(100 \% \%$ of employees) $\mathrm{N}=109$ & $\mathrm{N}=3670$ & \multirow{2}{*}{$0.082 * *$} \\
\hline Training difference: $\mathbf{0 . 1 1 6}$ & Training difference: $\mathbf{0 . 0 3 3}$ & \\
\hline \multicolumn{3}{|c|}{ Multiple treatments (after binary probits) } \\
\hline $\mathrm{PS}=1(<20 \%$ of employees $) \quad \mathrm{N}=82$ & $\mathrm{~N}=3431$ & \multirow{2}{*}{0.046} \\
\hline Training difference: $\mathbf{0 . 0 5 2}$ & Training difference: $\mathbf{0 . 0 0 6}$ & \\
\hline $\mathrm{PS}=1$ (20\%-99\% of employees) $\mathrm{N}=137$ & $\mathrm{~N}=3330$ & \multirow{2}{*}{0.011} \\
\hline Training difference: $\mathbf{0 . 0 4 0}$ & Training difference: $\mathbf{0 . 0 3 0}$ & \\
\hline $\mathrm{PS}=3$ ( $100 \% \%$ of employees) $\mathrm{N}=110$ & $\mathrm{~N}=3625$ & \multirow{2}{*}{$0.116 * * *$} \\
\hline Training difference: $\mathbf{0 . 1 1 5}$ & Training difference: $\mathbf{- 0 . 0 0 1}$ & \\
\hline
\end{tabular}

\section{Conclusion}

We investigate the impact of profit sharing intensity on training. In order to reduce possible selectivity effects a matching approach is applied which compares treated units with similar untreated units. Unobserved heterogeneity is removed by a conditional difference-indifferences approach.

Using a sample of German firms we find that the introduction of profit sharing significantly increases the share of employees who get trained. Hence, according to our results, collective performance pay works not only due to increased effort by the employees, but also because of higher participation in training courses. In our view this is an important contribution toward explaining the frequently observed higher productivity of companies with a sharing system.

\footnotetext{
${ }^{32}$ Again, other matching methods, such as kernel matching, lead to very similar results.

${ }^{33}$ We also carried out our analysis for the period 2001 to 2005, which leads to very similar results. The results are available from the authors upon request.

${ }^{34}$ Just like for the treatment "existence of profit sharing", with "introduction of profit sharing" as treatment variable we sometimes lose observations due to the common support restriction and because in some cases one of the industry dummies causes perfectly predicted failure in the probit estimations.
} 
Thus, profit sharing has a direct and an indirect impact. Such direct and indirect effects may also be present if other incentive schemes are applied. However, compared with collective payments they may work differently. For example tournaments will not presumably encourage cooperation at the workplace and are therefore more often observed if agents work in isolation. The comparison of the effectiveness and usefulness of incentive systems in different situations and surroundings appears to be a promising research area. Specific advantages in the use of a particular system and selectivity will probably not only be an issue with respect to profit sharing.

Incentives affect the performance of an organization in many different ways. Aside of human capital other factors determining the performance of an organization may be affected, such as innovativeness or investment. In our view future research should focus on the many indirect ways in which incentives work.

Most previous work of which we are aware takes profit sharing as a zero/one variable when applying company data, where all workers or none are covered. A crucial point of our approach is that we can observe and take into account the proportion of workers who are actually covered by a profit sharing scheme. To our knowledge there is no study taking into account the distribution of profit sharing intensity over establishments which has turned out to be very important for our results. The positive effects on training intensity are only present if the majority of the workforce participates in this group incentive payment. It would be interesting to test whether this effect is also present in other samples. 


\section{References}

Acemoglu, D. and J.-S. Pischke (1999a), The Structure of Wages and Investment in General Training, Journal of Political Economy, vol. 107, 539-572.

Acemoglu, D. and J.-S. Pischke (1999b), Beyond Becker: Training in Imperfect Labour Markets, Economic Journal, vol. 109, F112-F142.

Arulampalam, W., Booth, A. and M. Bryan (2004), Training in Europe, Journal of the European Economic Association, vol. 2, 346-360.

Azfar, O. and S. Danninger (2001), Profit-Sharing, Employment Stability, and Wage Growth, Industrial and Labor Relations Review, vol. 54, 619-630.

Bhargava, S. and T. Jenkinson (1995), Explicit Profit Sharing and the Determination of Wages: Microeconomic Evidence from the UK, Labour, vol. 9 (1), 73-95.

Becker, G. (1962), Investment into Human Capital: A Theoretical Analysis, Journal of Political Economy, vol. 70, 9-49.

Becker, G. (1964), Human Capital, Chicago: Chicago University Press.

Bellmann, L. and U. Leber (2007), Materielle Mitarbeiterbeteiligung: Geringe Verbreitung, aber hohe Intensität, IAB-Kurzbericht Nr. 13/2007.

Blasi, J. R., Freeman, R. B., Mackin, C. and D. L. Kruse (2008), Creating a Bigger Pie? The Effects of Employee Ownership, Profit Sharing, and Stock Options on Workplace Performance, NBER Working Papers: 14230.

Blundell, R. and M. Costa Dias (2009), Alternative Approaches to Evaluation in Empirical Microeconomics, Journal of Human Resources, vol. 44, 565-640. 
Cahuc, P. and B. Dormont (1997), Profit sharing: Does it increase productivity and employment? A theoretical model and empirical evidence on French micro data., Labour Economics, vol. 4, 293-319.

Chang, C. and Y. Wang (1996), Human Capital Investment under Asymmetric Information: The Pigouvian Conjecture Revisited, Journal of Labor Economics, vol. 14, 505-519.

Dehejia, R. and S. Wahba (2002), Propensity Score Matching Methods for Nonexperimental Causal Studies, The Review of Economics and Statistics, vol. 84, 151-161.

Doucouliagos, C. (1995), Worker Participation and Productivity in Labor-Managed and Participatory Capitalist Firms: A Meta-Analysis, Industrial and Labor Relations Review, vol. 49(1), 58-78.

FitzRoy, F. and K. Kraft (1987), Cooperation, Productivity and Profit Sharing, Quarterly Journal of Economics, vol. 102 (1), 23-35.

Frölich, M. (2008), A Note on Parametric and Nonparametric Regression in the Presence of Endogenous Control Variables, International Statistical Review, vol.76, 214-227.

Gielen, A. (2007), Performance Pay, Training and Labor Mobility, IZA Discussion Paper No. 2932.

Görg, H., Henry M. and E. Strobl (2008), Grant Support and Exporting Activity, The Review of Economics and Statistics, vol. 90(1), 168-174.

Hall, B. and J. Liebman (1998), Are CEOs Really Paid Like Bureaucrats?, Quarterly Journal of Economics vol. 113, 653-691.

Heckman, J.J., Ichimura, H. and P. Todd (1998), Matching as an Econometric Evaluation Estimator, Review of Economic Studies, vol. 65, 261-294. 
Huselid, M. (1995), The Impact of Human Resource Management Practices on Turnover, Productivity, and Corporate Financial Performance, Academy of Management Journal, vol. 38, 635-672.

Ichniowski, C., Shaw, K. and G. Prennushi, (1997), The Effects of Human Resource Management Practices on Productivity: A Study of Steel Finishing Lines, American Economic Review , vol. 87(3), 291-313.

Imbens, G. (2000), The Role of Propensity Score in Estimating Dose-Response Functions, Biometrika, vol. 87, 706-710.

Jensen, M. and K. Murphy (1990a), Performance Pay and Top-Management Incentives, Journal of Political Economy, vol. 98, 225-264.

Kandel, E. and E. Lazear (1992), Peer Pressure and Partnership. Journal of Political Economy, vol. 100, 801-817.

Katz, E. and A. Ziderman (1990), Investment in General Training: The Role of Information and Labour Mobility, Economic Journal, vol. 100, 1147-1158.

Kraft, K. and M. Ugarkovic (2007), Profit-Sharing: Supplement or Substitute?, mimeo, University of Dortmund.

Kruse, D.L. (1992), Profit Sharing and Productivity: Microeconometric Evidence from the United States, The Economic Journal, vol. 102 (410), 24-36.

Lechner, M. (2001), Identification and Estimation of Causal Effects of Multiple Treatments under the Conditional Independence Assumption, in: Lechner, M. and Pfeiffer, F. (eds.) Econometric Evaluation of Active Labor Market Policies, Heidelberg: Physika, 43-58.

Lechner, M. (2002a), Programme Heterogeneity and Propensity Score Matching: An Application to the Evaluation of Active Labour Market Policies, Review of Economics and Statistics, vol. 84(2), 205-220. 
Lechner, M. (2002b), Some Practical Issues in the Evaluation of Heterogeneous Labour Market Programmes by Matching Methods, Journal of the Royal Statistical Society: Series A, 165, Part 1,59-82.

Lechner, M., Miquel, R. and C. Wunsch (2007), The Curse and Blessing of Training the Unemployed in a Changing Economy: The Case of East Germany After Unification, German Economic Review, 8(4), 468-509.

Lechner, M.., Miquel, R. and C. Wunsch,, Long-run effects of public sector sponsored training in West Germany, Journal of the European Economic Association (forthcoming).

Lechner, M. and C. Wunsch (2009), Are training programs more effective when unemployment is high?, Journal of Labor Economics 27 (4): 653 - 692.

Leuven, E. (2005), The Economics of Private Sector Training: A Survey of the Literature, Journal of Economic Surveys, vol. 19, 91-111.

Möller, I. (2000), Produktivitätswirkung von Mitarbeiterbeteiligung. Mitteilungen aus der Arbeitsmarkt- und Berufsforschung, 4 565-582.

OECD (1995), Profit Sharing in OECD Countries, Employment Outlook, 139-169.

Parent, D. (2004), Incentives? The Effects of Profit Sharing Plans Offered by Previous Employers on Current Wages, Economics Letters, vol. 83, 37-42.

Predergast, C. and R. Topel (1993), Discretion and Bias in Performance Evaluation, European Economic Review, vol. 37, 355-365.

Poutsma, E. (2001), Recent Trends in Employee Financial Participation in the European Union, Luxembourg: Office for Official Publications of the European Commission.

Pendleton, A., Poutsma, E., van Ommeren, J. and Ch. Brewster (2003), The incidence and determinants of employee share ownership and profit sharing in Europe, in: Kato, T. and J. Pliskin (eds.): The Determinants of the Incidence and Effects of Participatory Organizations. 
Advances in the Economic Analysis of Participatory and Labor Management, vol. 7, JAI Press: Greenwich, CT.

Rosenbaum, P. and D. Rubin (1983), The Central Role of the Propensity Score in Observational Studies for Causal Effects. Biometrika, vol. 70, 41-55.

Rubin, D. (1977), Assignment to Treatment Group on the Basis of Covariate. Journal of Educational Statistics, vol. 2, 1-26.

Smith, J. and P. Todd (2005), Does Matching Overcome LaLonde's Critique of Nonexperimantal Estimators?, Journal of Econometrics, vol. 125, 305-353.

Stevens, M. (1994), Labour Contracts and Efficiency in on-the-job Training, Economic Journal, vol. 104, 408-419.

Wadhwani, S. and M. Wall, (1990), The Effects of Profit Sharing on Employment, Wages, Stock Returns and Productivity: Evidence from UK Micro Data, Economic Journal, vol. 100 (399), 1-17. 


\section{Appendix}

Table A1 - Mean values of profit-sharing and non-profit sharing firms in 2009

\begin{tabular}{|c|c|c|c|c|c|}
\hline Variable & $\begin{array}{l}\text { Firms without } \\
\text { profit sharing }\end{array}$ & $\begin{array}{l}\text { All firms with } \\
\text { profit sharing }\end{array}$ & $\begin{array}{c}\text { Firms with } \\
\text { profit sharing } \\
\text { for less than } \\
20 \% \text { of } \\
\text { employees } \\
\end{array}$ & $\begin{array}{c}\text { Firms with } \\
\text { profit sharing } \\
\text { for } 20 \%-99 \% \\
\text { of employees }\end{array}$ & $\begin{array}{l}\text { Firms with } \\
\text { profit sharing } \\
\text { for } 100 \% \text { of } \\
\text { employees }\end{array}$ \\
\hline Training intensity & 0.219 & $0.337 * * *$ & $0.253^{* *}$ & $0.377 * * *$ & $0.370 * * *$ \\
\hline Establishment size $<20$ & 0.518 & $0.224 * * *$ & $0.093 * * *$ & $0.330 * *$ & $0.244 * * *$ \\
\hline Establishment size 20-49 & 0.206 & $0.233^{*}$ & 0.234 & $0.262 * *$ & 0.205 \\
\hline Establishment size 50-249 & 0.214 & $0.355 * * *$ & $0.455^{* * *}$ & 0.253 & $0.359 * * *$ \\
\hline Establishment size 250-499 & 0.041 & $0.100 * * *$ & $0.131 * * *$ & $0.090 * * *$ & $0.084 * * *$ \\
\hline Establishment size 500+ & 0.022 & $0.088 * * *$ & $0.087 * * *$ & $0.064 * * *$ & $0.108 * * *$ \\
\hline Number of employees & 70.835 & $185.017 * * *$ & $176.333^{* * *}$ & $168.965^{* * *}$ & $204.406 * * *$ \\
\hline Shift responsibilities (dummy) & 0.136 & $0.248 * * *$ & $0.266 * * *$ & $0.244 * * *$ & $0.237 * * *$ \\
\hline Teamwork (dummy) & 0.073 & $0.136^{* * *}$ & $0.173^{* * *}$ & $0,131 * * *$ & $0.113^{* * *}$ \\
\hline $\begin{array}{l}\text { Independent work groups } \\
\text { (dummy) }\end{array}$ & 0.053 & $0.113^{* * *}$ & $0.144 * * *$ & $0,099 * * *$ & $0.099 * * *$ \\
\hline $\begin{array}{l}\text { Share of qualified employees } \\
\text { (percent) }\end{array}$ & 0.064 & $0.138 * * *$ & $0.103^{* * *}$ & $0.138 * * *$ & $0.161^{* * *}$ \\
\hline Collective bargaining (dummy) & 0.456 & $0.515^{* * *}$ & $0.574 * * *$ & 0.433 & $0.530 * * *$ \\
\hline Works council (dummy) & 0.216 & $0.470 * * *$ & $0.462 * * *$ & $0.375 * * *$ & $0.542 * * *$ \\
\hline Export share & 0.063 & $0.142 * * *$ & $0.136 * * *$ & $0.106^{* * *}$ & $0.171^{* * *}$ \\
\hline ICT investment (dummy) & 0.388 & $0.643 * * *$ & $0.628 * * *$ & $0.612 * * *$ & $0.677 * * *$ \\
\hline $\begin{array}{l}\text { Limited liability (dummy=1 if AG, } \\
\text { GmbH) }\end{array}$ & 0.616 & $0.824 * * *$ & $0.914 * * *$ & $0.708 * * *$ & $0.842^{* * *}$ \\
\hline $\begin{array}{l}\text { Age (dummy=1 if founded after } \\
\text { 1990) }\end{array}$ & 0.521 & $0.487 * *$ & 0.484 & $0.442 * * *$ & 0.519 \\
\hline $\begin{array}{l}\text { East German establishment } \\
\text { (dummy) }\end{array}$ & 0.420 & $0.364 * * *$ & $0.327 * * *$ & $0.330 * * *$ & 0.418 \\
\hline $\mathrm{N}$ & 4742 & 1075 & 312 & 312 & 443 \\
\hline
\end{tabular}


Table A2 - Results of probit estimations (Existence of profit sharing)

\begin{tabular}{lccc}
\hline Variables & PS=1/PS=0 & PS=2/PS=0 & PS=3/PS=0 \\
\hline Establishment size 20-49 & $0.678^{* * *}$ & $0.253^{* * *}$ & 0.102 \\
Establishment size 50-249 & $0.979^{* * *}$ & $0.236^{* *}$ & $0.186^{* *}$ \\
Establishment size 250-499 & $1.246^{* * *}$ & $0.462^{* * *}$ & 0.108 \\
Establishment size 500+ & $1.378^{* * *}$ & $0.447^{* *}$ & $0.564^{* * *}$ \\
Export share & 0.046 & $0.400^{* *}$ & $0.308^{* *}$ \\
Share of qualified employees & $0.571^{* *}$ & $0.510^{* *}$ & $0.859^{* * *}$ \\
Collective bargaining & -0.005 & $-0.225^{* * *}$ & 0.018 \\
Works council & 0.071 & 0.122 & $0.379^{* * *}$ \\
Limited liability & $0.444^{* * *}$ & $0.173^{* *}$ & $0.416^{* * *}$ \\
Age & 0.103 & -0.067 & 0.106 \\
East German establishment & $-0.148^{*}$ & -0.051 & 0.056 \\
Shift of responsibilities & $0.169^{* *}$ & $0.231^{* * *}$ & $0.226^{* * *}$ \\
Teamwork & $0.166^{*}$ & 0.104 & -0.092 \\
Independent work groups & $0.204^{*}$ & 0.061 & 0.074 \\
ICT investment & $0.183^{* * *}$ & $0.191^{* * *}$ & $0.361^{* * *}$ \\
\hline Number of observations & 5009 & 5043 & 5185 \\
Pseudo R2 & 0.195 & 0.165 & 0.205 \\
\hline
\end{tabular}

$* * * / * * / *$ indicates statistical significance at the $1 \%, 5 \%$ and $10 \%$ level.

Source: IAB Establishment Panel, wave 2009, own calculations (controlled remote data access via FDZ).

Note: Industry dummies are included in the analysis but are not reported.

Table A3 - Differences of mean values for multiple treatments after matching (Existence) - multinomial logit estimation

\begin{tabular}{lccc}
\hline Variables & PS=1/PS=0 & PS=2/PS=0 & PS=3/PS=0 \\
\hline Establishment size 20-49 & 0.003 & -0.013 & 0.026 \\
Establishment size 50-249 & 0.000 & -0.016 & -0.026 \\
Establishment size 250-499 & -0.001 & 0.016 & 0.015 \\
Establishment size 500+ & 0.001 & 0.014 & 0.001 \\
Export share & 0.021 & -0.004 & 0.001 \\
Shift responsibilities & -0.011 & -0.013 & 0.017 \\
Teamwork & -0.017 & -0.018 & 0.020 \\
Independent work groups & -0.006 & 0.021 & 0.023 \\
Share of qualified employees & 0.016 & 0.022 & 0.009 \\
Collective bargaining & -0.032 & 0.037 & 0.003 \\
Works council & 0.026 & 0.026 & -0.029 \\
ICT investment & -0.016 & 0.019 & -0.024 \\
Limited liability & -0.008 & -0.014 & -0.014 \\
Age & 0.006 & 0.008 & -0.027 \\
East German establishment & 0.037 & 0.001 & -0.042 \\
\hline
\end{tabular}

***/**/* indicates statistical significance at the 1\%, 5\% and $10 \%$ level.

Source: IAB Establishment Panel, wave 2009, own calculations (controlled remote data access via FDZ). 
Table A4 - Differences of mean values for multiple treatments after matching (Existence) - binary probit estimations

\begin{tabular}{lccc}
\hline Variables & PS=1/PS=0 & PS=2/PS=0 & PS=3/PS=0 \\
\hline Establishment size 20-49 & 0.013 & 0.013 & 0.010 \\
Establishment size 50-249 & -0.022 & -0.011 & 0.007 \\
Establishment size 250-499 & 0.005 & -0.010 & -0.002 \\
Establishment size 500+ & 0.005 & 0.013 & 0.000 \\
Export share & 0.016 & 0.004 & 0.017 \\
Shift responsibilities & -0.005 & 0.018 & -0.018 \\
Teamwork & 0.005 & -0.002 & -0.024 \\
Independent work groups & 0.013 & 0.013 & 0.009 \\
Share of qualified employees & 0.005 & -0.012 & -0.004 \\
Collective bargaining & 0.000 & 0.035 & 0.001 \\
Works council & 0.006 & -0.014 & -0.018 \\
ICT investment & 0.047 & -0.014 & -0.007 \\
Limited liability & 0.006 & -0.014 & 0.003 \\
Age & -0.029 & -0.059 & -0.037 \\
East German establishment & 0.002 & -0.024 & -0.038 \\
$* * * * * *$ indicates statistical significan & &
\end{tabular}

$* * * / * * / *$ indicates statistical significance at the $1 \%, 5 \%$ and $10 \%$ level.

Source: IAB Establishment Panel, wave 2009, own calculations (controlled remote data access via FDZ).

Table A5 - Average treatment effects on the treated for binary treatments 2009

\begin{tabular}{|c|c|c|}
\hline Treatment group & Matched firms without profit sharing & Training difference \\
\hline \multicolumn{3}{|l|}{ Matching } \\
\hline $\begin{array}{l}\text { All firms with profit sharing } \mathrm{N}=1072 \\
\text { Training intensity: } \mathbf{0 . 3 3 7}\end{array}$ & $\begin{array}{l}\mathrm{N}=4742 \\
\text { Training intensity: } \mathbf{0 . 2 6 5}\end{array}$ & $0.072 * * *$ \\
\hline \multicolumn{3}{|l|}{ Conditional difference-in-differences } \\
\hline $\begin{array}{l}\text { All firms with profit sharing } \mathrm{N}=333 \\
\text { Training difference: } \mathbf{0 . 0 7 0}\end{array}$ & $\begin{array}{l}\mathrm{N}=3659 \\
\text { Training difference: } \mathbf{0 . 0 0 4}\end{array}$ & $0.066 * * *$ \\
\hline
\end{tabular}

Training difference: $\mathbf{0 . 0 7 0} \quad$ Training difference:

Source: IAB Establishment Panel, waves 2007-2009, own calculations (controlled remote data access via FDZ).

Note: Industry dummies are included in the analysis but are not reported. 
Table A6 - Results of probit estimations (Introduction of profit sharing)

\begin{tabular}{lccc}
\hline Variables & PS=1/PS=0 & PS=2/PS=0 & PS=3/PS=0 \\
\hline Establishment size 20-49 & $1.015^{* * *}$ & $0.200^{*}$ & -0.011 \\
Establishment size 50-249 & $1.198^{* * *}$ & 0.058 & 0.038 \\
Establishment size 250-499 & $1.975^{* * *}$ & 0.022 & -0.218 \\
Establishment size 500+ & $1.489^{* * *}$ & 0.176 & 0.140 \\
Export share & 0.051 & $0.460^{* *}$ & 0.312 \\
Share of qualified employees & -0.064 & $0.783^{* * *}$ & $0.560^{*}$ \\
Collective bargaining & -0.036 & -0.088 & $-0.281^{* * *}$ \\
Works council & 0.150 & 0.161 & $0.310^{* *}$ \\
Limited liability & $0.377^{* *}$ & 0.150 & $0.309^{* *}$ \\
Age & 0.082 & $-0.205^{* *}$ & 0.040 \\
East German establishment & -0.093 & 0.028 & -0.027 \\
Shift of responsibilities & -0.061 & 0.110 & 0.182 \\
Teamwork & 0.159 & 0.168 & 0.165 \\
Independent work groups & 0.258 & 0.101 & 0.149 \\
ICT investment & 0.123 & $0.171^{*}$ & $0.193^{*}$ \\
\hline Number of observations & 3513 & 3467 & 3735 \\
Pseudo R2 & 0.206 & 0.091 & 0.123 \\
\hline
\end{tabular}

$* * * / * * / *$ indicates statistical significance at the $1 \%, 5 \%$ and $10 \%$ level.

Source: IAB Establishment Panel, waves 2007-2009, own calculations (controlled remote data access via FDZ).

Note: Industry dummies are included in the analysis but are not reported.

Table A7 - Differences of mean values for multiple treatments after matching (Introduction) multinomial logit estimation

\begin{tabular}{lccc}
\hline Variables & PS=1/PS=0 & PS=2/PS=0 & PS=3/PS=0 \\
\hline Establishment size 20-49 & 0.018 & -0.044 & -0.041 \\
Establishment size 50-249 & 0.018 & 0.063 & 0.032 \\
Establishment size 250-499 & -0.024 & 0.011 & -0.018 \\
Establishment size 500+ & -0.012 & -0.004 & -0.005 \\
Export share & 0.016 & 0.003 & -0.015 \\
Shift responsibilities & 0.049 & 0.011 & -0.028 \\
Teamwork & 0.018 & -0.033 & 0.000 \\
Independent work groups & 0.030 & 0.007 & 0.013 \\
Share of qualified employees & 0.011 & -0.002 & 0.011 \\
Collective bargaining & 0.030 & -0.007 & 0.041 \\
Works council & 0.006 & 0.037 & -0.018 \\
ICT investment & 0.012 & -0.019 & 0.037 \\
Limited liability & -0.024 & 0.033 & 0.018 \\
Age & -0.061 & 0.000 & 0.050 \\
East German establishment & -0.006 & -0.070 & -0.009 \\
\hline
\end{tabular}

$* * * * * / *$ indicates statistical significance at the $1 \%, 5 \%$ and $10 \%$ level.

Source: IAB Establishment Panel, waves 2007-2009, own calculations (controlled remote data access via FDZ). 
Table A8 - Differences of mean values for multiple treatments after matching (Introduction) - binary probit estimations

\begin{tabular}{|c|c|c|c|}
\hline Variables & $\mathbf{P S}=1 / \mathrm{PS}=\mathbf{0}$ & $\mathbf{P S}=2 / \mathbf{P S}=0$ & $\mathbf{P S}=3 / \mathbf{P S}=\mathbf{0}$ \\
\hline Establishment size 20-49 & -0.012 & -0.015 & 0.040 \\
\hline Establishment size 50-249 & 0.000 & 0.018 & 0.005 \\
\hline Establishment size 250-499 & 0.000 & 0.000 & -0.018 \\
\hline Establishment size 500+ & 0.012 & -0.010 & 0.005 \\
\hline Export share & -0.022 & 0.012 & 0.020 \\
\hline Shift responsibilities & 0.012 & 0.007 & -0.018 \\
\hline Teamwork & 0.012 & 0.022 & -0.046 \\
\hline Independent work groups & 0.000 & 0.015 & -0.032 \\
\hline Share of qualified employees & 0.010 & 0.020 & 0.003 \\
\hline Collective bargaining & -0.012 & 0.015 & 0.059 \\
\hline Works council & 0.012 & -0.004 & 0.032 \\
\hline ICT investment & 0.000 & 0.000 & -0.014 \\
\hline Limited liability & -0.018 & 0.000 & -0.005 \\
\hline Age & -0.012 & 0.062 & 0.018 \\
\hline East German establishment & -0.037 & -0.004 & 0.009 \\
\hline
\end{tabular}

Source: IAB Establishment Panel, waves 2007-2009, own calculations (controlled remote data access via FDZ). 